\title{
PREDICTIVE FACTORS OF EMPLOYEES SATISFACTION IN TELECOMMUNICATION CALL CENTRE SECTOR IN TURKEY: A CASE STUDY WITH STRUCTURAL EQUATION MODEL
}

\author{
TÜRKIYE'DE TELEKOMÜNIKASYON ÇAĞRI MERKEZI SEKTÖRÜNDE \\ ÇALIŞAN MEMNUNIYETININN BELIRLEYICI FAKTÖRLERİ: YAPISAL \\ EŞITLIK MODELI ILE INCLENMESI
}

Rıdvan KESKİN ${ }^{(1)}$, Sadullah LUDERS ${ }^{(2)}$, Artun TOPAÇ(3)

\begin{abstract}
Factors affecting employee satisfaction in call centres in Turkey is examined with questionnaire technique through analysing their frequency, Exploratory Factor Analysis (EFA), and factors with t-test and ANOVA, and finally Structural Equation Modelling (SEM). There are significant differences for employee perception of in-service training between age groups, and also differences skills \& performance development opportunities (F5) between various education levels. SEM analysis show that five factors affecting their satisfaction are respectively employees' perception of collaboration and teamwork (F3), skills \& performance development opportunities (F5), employees' perception of employers' management style (F1), employees' perception of in-service training (F2), and employees' perception of working conditions (F4).
\end{abstract}

Keywords: Employee Satisfaction, ANOVA Test, Structural Equation Modelling, Call Centers

Öz: Türkiye'deki çağrı merkezlerinde çalışan memnuniyetini etkileyen faktörler anket tekniği kullanilarak frekans analizi, Açımlayıcı Faktör Analizi (EFA) analizi, t-testi ve ANOVA ve son olarak Yapisal Eşitlik Modellemesine (SEM) bakilarak incelenmistir. Bu analizler çalışanların hizmet içi eğitim algısında yaş grupları arasında önemli farklılıkların olduğunu ve bununla birlikte çeşitli eğitim seviyeleri arasında beceri ve performans geliştirme firsatları (F5) farklılıklarin bulunmuştur. SEM analizi ile bulunan memnuniyetlerini etkileyen beş faktörün strasiyla, çalışanların işbirliği ve ekip çalışması algısı (F3), beceri ve performans geliştirme firsatları (F5), çalışanların işverenlerin yönetim tarzı algısı (F1), çalışanların hizmet içi eğitim algısı (F2) ve çalışanların çalışma koşulları (F4) algısı olduğu belirlenmiştir.

Anahtar Kelimeler: Çalışan Memnuniyeti, ANOVA Testi, Yapısal Eşitlik Modeli, Çă̆rı Merkezi

JEL: C38, C83, C12

\section{Introduction}

Nowadays, companies are required to develop new and differentiated market strategies by means of their call centres in order to improve their positions in the markets and to make forward-looking initiatives. In Turkey, there is a similar trend that these call centres have become an important function in the companies. As call centres industry with their telecommunication tools continue to expand in their

\footnotetext{
(1) Manisa Celal Bayar University, Faculty of Economics and Administrative Sciences; ridvankeskin69@gmail.com, ORCID: 0000-0001-5472-0976

(2) Robert Gordon University, School of Nursing and Midwifery; s.e.luders@rgu.ac.uk, ORCID: 0000-0002-0810-909X

(3) Statistician, İzmir, Turkey; artuntopac@gmail.com

Geliş/Received: 03-09-2019; Kabul/Accepted: 10-07-2020
} 
communication channels, these centres have been found to be effective in acquiring new customers, retaining existing customers, and increasing their loyalty (Yang, Ju, and Lee,2016:29; Choi, Cheong and Feinberg, 2012: 493). Although there is a strong link between performing their job well and providing high quality service results in being satisfied with their job amongst call centre employees, many call centres tend to miss the link 'between employee satisfaction, service quality, customer satisfaction and profitability (Marr and Parry, 2004: 58; Choi et al. 2012: 496). This often cause demoralisation, sickness, exhaustion and subsequently, employee turnover or absenteeism (Poddar and Madupalli, 2012: 556). A recent study from Callaghan (2017) suggests pay, recognition and promotion were key motivational factors for employees in call centre.

Call centres customers can mostly communicate to employees via emails, SMS or even social media. In a broader sense, telecommunication occurs when exchange of information between participants using technology through different forms of communication. From employees' perspectives, a call centre consists of three separate functions as engaging in specialist operations linking telecommunications and information systems technologies; working in a controlled environment with monitoring of performance; and being in direct discussions with the customers via phone calls, emails, SMS, and internet forums (Richardson and Gillespie, 2003: 103; Kisiel, 2013: 12). While a wide range of technology such as machine learning, artificial intelligence, system automation, analytics, workflow technology, bots and verification system are currently deployed to increase efficiency, effectiveness and enhance organisational learning experience for productivity and teamwork (Syam and Sharma, 2018: 145; Anagnoste 2018: 68), the range of skills required by call centre employees are also developed by becoming problem solvers, educators, trainer, cocreators of positive experiences, and brand-enhancing ambassadors (Cottam, 2020: 4). Therefore, investing in human resources practices supporting employee development activities will pay off in terms of improving both employee and customer satisfaction within call centres (Chicu, del Mar Pàmies, Ryan, and Cross, 2019: 91). Meanwhile, working environment in call centres often becomes stressful dealing with problematic customer behaviours (Poddar and Madupalli, 2012: 556), getting both positive and negative feedback at work can have a promising impact on performance of call centre workers (Callaghan, 2017: iv). Noticeably, there is a tension between employees' self-reported satisfaction and their managers' perception of employee satisfaction in call centres because the management in call centres pressurising their employees with excessive performance measurement, monitoring, and lack of control can lead to stress, unhappiness and dissatisfaction (Kisiel, 2013: 29). Furthermore, increasing communication, collaboration and trust contributes to project performance in call centres. Finally, emotional motivation as positive impact and emotional pressure as negative impact often emerge as an important topic, suggesting that further research should include the extent to which emotional engagement is managed as part of the call centre employment and satisfaction (Rose and Wright, 2005: 155).

The aim of the study is to investigate call centre employee satisfaction in telecommunication sector as being the largest call centre industry in Turkey. Henceforth, the next section will examine the call centre structures in relation to Turkey. Following a survey amongst call centre employees in this sector, the data allow the researchers to analyse demographic properties with their frequency, exploratory factor analysis to understand the survey questions, analysis of relationships between of demographic characteristics variables and factors obtained 
with t-test and ANOVA, and finally evaluation of structural equation modelling in the call centres under the observation conditions.

\section{Call Centre Industry in Turkey}

In parallel to rapid changes related to Covid-19 pandemics in the world, importance of telecommunication tools has increasingly recognised in Turkey because call centre employees have been key workers under the government's lockdown guidance in Turkey (Doğrular, 2020). For this purpose, it is anticipated that the telecommunication call center will further increase its importance with rising demand adds pressure to the products and services, which affects service levels at call centres. Based on the Call Center Association (2019) annual report, call center employees are mainly employed in 12 different industries in Turkey including telecommunication (33\%), finance $(16 \%)$, public services $(16 \%)$, informatics $(6 \%)$, e-commerce $(6 \%)$, consumer products $(5 \%)$, logistics $(4 \%)$, energy \& infrastructure $(4 \%)$, retails spots $(3 \%)$, health $(2 \%)$, entertainment \& media $(2 \%)$, and tourism $(1 \%)$ and others $(2 \%)$. In addition, the total number of employees in call centres industry is 115.000 , with its support and management staff, including 102.000 as customer representatives in 2019.

Although Istanbul province has the largest proportion of call centres in Turkey, some of these call centres in Istanbul have been moved to Anatolia due to increasing living costs, fast growing population, and excessive employee circulation in recent years in Eastern and South-eastern Anatolian provinces (SERKA, 2011: 34; Çelik, 2016: 1447). In terms of employment distribution, this trend continues in call centre industry as Istanbul (35\%), İzmir (10\%), and Ankara (4\%), while the remaining $51 \%$ is distributed to the provinces in Anatolia (Call Center Association, 2019: 10). Finally, according to the Call Center Association Market Research Report in Turkey (Call Center Association, 2017: 70), a SWOT analysis (Strengths, Weaknesses, Opportunities, Threats) demonstrates that while the strength of call centre employees are dynamic and youthful structure of employees, educated and young population of employees, and ability to produce flexible solutions of employees; the weaknesses are employee satisfaction-service quality relationship, cost pressure - low wage policy, legal regulation needs, and lack of control.

\section{Aims and Objectives}

The aim of this research project is to examine the factors affecting the satisfaction of call centres employees in Turkey.

Our objectives are:

- To help manager of call centres manage and motivate their staff more effectively

- To improve the working environment in call centres

- To reduce the employee turnover rates in call centres 


\section{Methodology}

Due to its popularity as a growing industry in Turkey, there have been many scientific studies about call centres. However, in these studies, satisfaction of call center employees has not been addressed explicitly. Following a survey amongst call centre employees in this sector, the data allow the researchers to analyse demographic properties with their frequency, exploratory factor analysis to understand the survey questions, analysis of relationships between of demographic characteristics variables and factors obtained with t-test and ANOVA, and finally evaluation of structural equation modelling in the call centres under the observation conditions.

\subsection{Data cluster and Sample Volume}

In this study, data were collected by means of questionnaire technique. The questionnaire was prepared using a five-point Likert scale (Very satisfied, Satisfied, Neither satisfied nor dissatisfied, Dissatisfied and Very dissatisfied). The survey consists of two parts. In the first part, there are question items for collecting the demographic features of the employees in the call center, and in the second part, the question items that aim to measure the satisfaction of the employees in the call center. There are five questions in the first part and twenty-four questions in the second part. The survey was applied to 318 people in a call center with 350 call center employees operating on telecommunications in İzmir province. However, since missing information was found in 18 questionnaire forms, it was excluded from the evaluation. Therefore, in this scientific study, the sample volume consists of 300 call center employees.

\subsection{Data analysis through the exploratory approach}

Accuracy of statistical analysis depend on validity and reliability of its (survey) tool. Validity of the survey was achieved through a Delphi method. A Delphi consensus process was used a panel of experts to generate a list of survey categories and questions in this study. This was achieved through multiple rounds of questionnaire sent to a panel of experts for their selection (Berman, Jackson, Miller, Kowalski, Kolm and Luks, 2018: 1593).

Reliability of the (survey) tool was attained by the controlling Cronbach's Alpha $(\alpha)$ value. The Cronbach's Alpha value using 24 question items (excluding questionnaires related to demographic characteristics) in the study is 0.927 . The fact that the $\alpha$ value is greater than 0.70 indicates that the questionnaire items are consistent in itself and measure the subject matter very well (Gürbüz and Şahin, 2014: 292).

Analysis of the data in the study includes:

Step 1: Frequency distribution table representation of the survey participants' demographic characteristics

Step 2: Exploratory Factor Analysis (EFA) to understand the survey questions

Step 3: Analysis of relationships between of demographic characteristics variables and factors by means of $t$-test and ANOVA

Step 4: Evaluation of structural equation modelling in the call centres under the observation conditions. 
Statistical Package for Social Sciences (SPSS 23) is used for statistical analysis of survey data.

\section{Step 1:}

Table 1 demonstrates frequency distribution of the survey participants $($ Total $=300)$ in their demographic characteristics.

Table 1. Participants with Their Demographic Characteristics

\begin{tabular}{|c|c|c|c|c|c|}
\hline Age & $\begin{array}{l}\text { Frequency } \\
\text { (F) }\end{array}$ & $\%$ & Gender & $\begin{array}{l}\text { Frequency } \\
\text { (F) }\end{array}$ & $\%$ \\
\hline $18-21$ & 23 & 7.7 & Male & 79 & 26.3 \\
\hline $22-25$ & 93 & 31.0 & Female & 221 & 73.7 \\
\hline $26-29$ & 103 & 34.3 & Total & 300 & 100.0 \\
\hline $30-33$ & 44 & 14.7 & Marital status & $\mathbf{F}$ & $\%$ \\
\hline $34 \&$ Over & 37 & 12.3 & Married & 80 & 26.7 \\
\hline Total & 300 & 100.0 & Single & 220 & 73.3 \\
\hline $\begin{array}{l}\text { Employment } \\
\text { Period }\end{array}$ & $\mathbf{F}$ & $\%$ & Total & 300 & 100.0 \\
\hline 1-5 Months & 80 & 26.7 & Education Level & $\mathbf{F}$ & $\%$ \\
\hline 6-11 Months & 47 & 15.7 & Primary School & 6 & 2.0 \\
\hline 12-17 Months & 40 & 13.3 & High School & 104 & 34.7 \\
\hline 18-23 Months & 27 & 9.0 & $\begin{array}{l}\text { College (Further } \\
\text { Education) }\end{array}$ & 85 & 28.3 \\
\hline $\begin{array}{l}24 \text { Months \& } \\
\text { Over }\end{array}$ & 106 & 35.3 & Undergraduate Degree & 100 & 33.3 \\
\hline \multirow[t]{2}{*}{ Total } & 300 & 100.0 & Postgraduate Degree & 5 & 1.7 \\
\hline & & & Total & 300 & 100.0 \\
\hline
\end{tabular}

In table 1, demographic characteristics of the participants are grouped into five categories: age, employment period, gender, marital status and educational status. Under age category; the largest group is 26-29 age (34\%), followed by 22-25 age group (31\%) amongst the participants whereas $18-21$ age group is the smallest. In this study, remarkably, only just a third (35\%) has been working for more than two years in call centres. When shorter than 24 months' employment period considered, the longest employment period is 1-5 months (27\%) as compared to 6-11 months (16\%), 12-17 months (13\%) and 18-23 months (9\%). Meanwhile, while $26 \%$ of the participants are male, $74 \%$ are female in the study. Besides, a similar ratio can be observed in their marital status as $27 \%$ married and $73 \%$ single in the study. Under education category; the largest group is high school (35\%), followed by undergraduate degree $(33 \%)$, college $(28 \%)$ amongst the participants whereas postgraduate degree and primary school level of education are around $2 \%$ age group being the smallest. According with the findings in Turkey-wide call centre data in 2019 female employee rate in the call centre is $66 \%$. However, the findings in this study equates to $74 \%$ in 300 employees (Table 1). Meanwhile, the majority of call centre's workers are in younger age groups (post-university degree level) between 22-25 and 26-29, equating $65 \%$ of its workforce in the study. Besides, contradicting with Turkey-wide statistics 
(62\% university graduate), measurement of participants' education level in the study show that the majority $(63 \%)$ has high school and College ( 2 years' pre-university degree) levels, compared to $33 \%$ university education level. This indicates that the workers to be relatively new in working life, female, single and young graduates. As their working period in call centres are relatively low (65\% until 24 months), this would imply that the call centre workers consider their employment to gain a position in the job market rather than as a career option (Singh and Pandey, 2005: 685).

\section{Step 2: EFA results}

EFA is one of the multivariate statistical methods used in the creation of subdimensions (factors) for easier understanding, interpretation and testing of questionnaire items. In order to apply EAF to the survey, Kaiser-Meyer-Olkin (KMO) and Bartlett's Sphericity test value must be controlled. In this study, the "Varimax Rotation" method is used. As a result of the rotation process, when the load scores of any question item in the factors are too close to each other, the question item causes to become undetermined in which factor it should belong to. In this case, such a problematic question item is excluded from analysis. In this study, as question item 17 (i.e. Q17) became problematic question, this item is excluded from the analysis. Furthermore, when the rest of the survey questions in Table 3 is considered for 23 questions, KMO value is 0.918 and p value of Bartlett's Sphericity test is 0.00 . When the first value greater than 0.60 , this value indicates that the sample volume is large enough for factor analysis application. Moreover, if the second value is less than 0.05 , the question items show that the correlation matrix is ideal for factor analysis. Table 2 shows the eigenvalues for finding the number of factors and the total explained variance percentages of the factors obtained after rotation.

Table 2. Eigenvalues and Variance Explanation Percentage (\%)

\begin{tabular}{|c|c|c|c|c|c|c|}
\hline \multirow{2}{*}{$\begin{array}{c}\text { Component } \\
\text { (Factor) }\end{array}$} & \multicolumn{3}{|c|}{ Initial Eigenvalues } & \multicolumn{3}{c|}{$\begin{array}{c}\text { Rotation Sums of Squared } \\
\text { Loadings }\end{array}$} \\
\cline { 2 - 7 } & Total & $\begin{array}{c}\text { \% of } \\
\text { Variance }\end{array}$ & $\begin{array}{c}\text { \% of } \\
\text { Cumulative }\end{array}$ & Total & $\begin{array}{c}\text { \% of } \\
\text { Variance }\end{array}$ & $\begin{array}{c}\text { \% of } \\
\text { Cumulative }\end{array}$ \\
\hline $\mathbf{1}$ & 9.197 & 39.989 & 39.989 & 4.454 & 19.364 & 19.364 \\
\hline $\mathbf{2}$ & 2.602 & 11.312 & 51.3 & 3.624 & 15.757 & 35.151 \\
\hline $\mathbf{3}$ & 1.768 & 7.687 & 58.987 & 2.954 & 12.844 & 47.965 \\
\hline $\mathbf{4}$ & 1.166 & 5.069 & 64.055 & 2.607 & 11.335 & 59.301 \\
\hline $\mathbf{5}$ & 1.104 & 4.802 & 68.857 & 2.198 & 9.556 & 68.857 \\
\hline $\mathbf{6}$ & 0.85 & 3.695 & 72.552 & & & \\
\hline
\end{tabular}

When determining number of factors by examining at the eigenvalues, the number of factors with eigenvalue greater than 1 is determined. In Table 2, the smallest eigenvalue (1.104) whose eigenvalue is greater than 1 is linked to the fifth component (factor). In the last column of Table 2, cumulative totals of the variance percentages are explained after the rotation of the five factors. Accordingly, these five factors explain $68.857 \%$ of the total variance. According to variance explanation percentages of each factor, order of importance is as follows; The first factor (F1) with a rate of $19.364 \%$, the second factor (F2) with $15.757 \%$, the third factor (F3) with $12.844 \%$, the fourth factor (F4) with $11.335 \%$ and the least important factor (F5) with $9.556 \%$. Properties of these factors are shown in Table 3 below. 
Table 3. Properties of factors

\begin{tabular}{|c|c|c|c|}
\hline $\begin{array}{l}\text { Factor } \\
\text { No }\end{array}$ & Survey Question (Q) & $\begin{array}{l}\text { Factor } \\
\text { Loads }\end{array}$ & $\begin{array}{l}\text { Alpha } \\
\text { Value }\end{array}$ \\
\hline \multirow{6}{*}{ F1 } & $\begin{array}{l}\text { Q4. (I am satisfied that) my employer creates opportunities and } \\
\text { finds alternative solutions. }\end{array}$ & 0.807 & \multirow{6}{*}{0.907} \\
\hline & $\begin{array}{l}\text { Q2. (I am satisfied that) my employer thinks about and listens } \\
\text { the employee issues. }\end{array}$ & 0.783 & \\
\hline & $\begin{array}{l}\text { Q3. (I am satisfied that) my employer takes care of employee } \\
\text { and values employee contributions. }\end{array}$ & 0.780 & \\
\hline & $\begin{array}{l}\text { Q5. (I am satisfied that) my employer appreciates the work } \\
\text { being done and employee achievements. }\end{array}$ & 0.763 & \\
\hline & $\begin{array}{l}\text { Q1. (I am satisfied that) my employer plans and manages the } \\
\text { employee workload. }\end{array}$ & 0.729 & \\
\hline & $\begin{array}{l}\text { Q6. (I am satisfied that) my employer is fair and the workload } \\
\text { has a balanced distribution. }\end{array}$ & 0.718 & \\
\hline \multirow{4}{*}{ F2 } & $\begin{array}{l}\text { Q8. (I am satisfied with) the subjects (relevance)of the training } \\
\text { sessions that I attended. }\end{array}$ & 0.853 & \multirow{4}{*}{0.917} \\
\hline & $\begin{array}{l}\text { Q7. (I am satisfied with) the content of the training sessions } \\
\text { that I attended. }\end{array}$ & 0.849 & \\
\hline & $\begin{array}{l}\text { Q9. (I am satisfied with) the timing of the training sessions that } \\
\text { I attended. }\end{array}$ & 0.816 & \\
\hline & $\begin{array}{l}\text { Q10. (I am satisfied with) the trainers in these sessions that I } \\
\text { attended. }\end{array}$ & 0.807 & \\
\hline \multirow{4}{*}{$\mathbf{F 3}$} & $\begin{array}{l}\text { Q22. (I am satisfied with) the habit of support and collabration } \\
\text { at work. }\end{array}$ & 0.766 & \multirow{4}{*}{0.861} \\
\hline & $\begin{array}{l}\text { Q24. (I am satisfied with) collective use of the shared } \\
\text { knowledge at work. }\end{array}$ & 0.711 & \\
\hline & $\begin{array}{l}\text { Q23. (I am satisfied with) my employers dealing with the } \\
\text { employees' personal problems. }\end{array}$ & 0.709 & \\
\hline & $\begin{array}{l}\text { Q21. (I am satisfied with) the habit of communication between } \\
\text { employers and employees. }\end{array}$ & 0.677 & \\
\hline \multirow{6}{*}{ F4 } & $\begin{array}{l}\text { Q19. (I am satisfied with) my performance recorded on the } \\
\text { computer systems. }\end{array}$ & 0.713 & \multirow{6}{*}{0.768} \\
\hline & Q13. (I am satisfied with) employees' lunch break provided. & 0.686 & \\
\hline & $\begin{array}{l}\text { Q20. (I am satisfied that) our computer program is suitable and } \\
\text { sufficient. }\end{array}$ & 0.650 & \\
\hline & Q16. (I am satisfied with) the layout of our office space. & 0.627 & \\
\hline & $\begin{array}{l}\text { Q15. (I am satisfied with) the facilities for lunch, coffee and } \\
\text { soft-drinks etc. }\end{array}$ & 0.559 & \\
\hline & $\begin{array}{l}\text { Q18. (I am satisfied with) the monitoring and implementation } \\
\text { of new technologies at work. }\end{array}$ & 0.421 & \\
\hline F5 & $\begin{array}{l}\text { Q11. (I am satisfied with) demonstrate my abilities and skills } \\
\text { at work. }\end{array}$ & 0.791 & 0.869 \\
\hline
\end{tabular}




\begin{tabular}{|l|l|}
\hline $\begin{array}{l}\text { Q14. (I am satisfied with) my application of innovation at } \\
\text { work. }\end{array}$ & 0.746 \\
\hline $\begin{array}{l}\text { Q12. (I am satisfied with) learning new things to improve } \\
\text { myself at my work. }\end{array}$ & 0.714 \\
\hline
\end{tabular}

When considering characteristics of each survey item (Q1, Q2, .., Q24), the related factors are grouped and named respectively into five different factors as follows:

- F1: Employees Perception of Employers' Management Style,

- F2: Employees Perception of In-Service Training,

- F3: Employees Perception of Collaboration and Teamwork,

- F4: Employees Perception of Working Conditions,

- F5: Employees Perception of Skills \& Performance Development Opportunities.

Coefficients of factors being greater than 70 indicates that the question items are representing its factors well and consistent in themselves.

\section{Step 3:}

Independent sample t-test is used for the analysis of gender variable. The null hypotheses by gender of the respondents are:

- $\mathrm{H}_{01}$ : There is no significant difference in their opinion for employees' perception of employers' management style (F1) between genders.

- $\mathrm{H}_{02}$ : There is no significant difference in their opinion for employees' perception of in-service training (F2) between genders.

- $\mathrm{H}_{03}$ : There is no significant difference in their opinion for employees' perception of collaboration and teamwork (F3) between genders.

- $\mathrm{H}_{04}$ : There is no significant difference in their opinion for employees' perception of working conditions (F4) between genders.

- $\mathrm{H}_{05}$ : There is no significant difference in their opinion for employees' perception of Skills \& Performance development opportunities (F5) between genders.

Below, table 4 provides t-test results of the above hypotheses.

Table 4. T-test Statistical Analysis

\begin{tabular}{|c|c|c|c|c|}
\hline Null Hypothesis & $\mathbf{t}$ & df & $\mathbf{P}$ & $\begin{array}{c}\text { Decision of } \\
\text { Hypothesis* }\end{array}$ \\
\hline $\mathrm{H}_{01}$ & -2.022 & 298 & 0.044 & Rejected \\
\hline $\mathrm{H}_{02}$ & -0.040 & 298 & 0.968 & Accepted \\
\hline $\mathrm{H}_{03}$ & 1.527 & 298 & 0.128 & Accepted \\
\hline $\mathrm{H}_{04}$ & 0.341 & 298 & 0.733 & Accepted \\
\hline $\mathrm{H}_{05}$ & -2.984 & 298 & 0.003 & Rejected \\
\hline$* 5 \%$ validity of significance level \\
\hline
\end{tabular}

Based on the findings in Table $4, \mathrm{H}_{01}$ and $\mathrm{H}_{05}$ hypotheses were rejected at 5\% significance level. Therefore, it can be implied that there are statistically significant differences for Employees' Perception of Employers' Management Style (F1) 
between genders in call centres. Similarly, it can be implied that there are statistically significant differences for Employees' Perception of Skills \& Performance Development Opportunities (F5) between genders. On the other hand, as p values in $\mathrm{H}_{02}, \mathrm{H}_{03}$ and $\mathrm{H}_{04}$ hypothesis are bigger than 0.05 , these hypotheses are accepted. This implies that there are no statistically significant differences for F2, F3 and F4 factors between genders.

To understand any statistically meaningful differences for factor values between demographic characteristics groups (i.e. age, employment period and education level), ANOVA analysis is used. Below is the list of null hypothesis for age, employment period and education level variables:

- $\mathrm{H}_{01 \mathrm{i}}$ : There is no statistically significant difference in their opinion for Fi between age groups $(\mathrm{i}=1,2, \ldots, 5)$

- $\mathrm{H}_{02 \mathrm{i}}$ : There is no statistically significant difference in their opinion for $\mathrm{Fi}$ between employment periods $(i=1,2, \ldots, 5)$

- $\mathrm{H}_{03 \mathrm{i}}$ : There is no statistically significant difference in their opinion for $\mathrm{Fi}$ between education levels $(i=1,2, \ldots, 5)$

Table 5 shows results of Levene test statistics of the relevant hypotheses to meet the homogeneity assumptions (Homoscedasticity). Then when assumption of homogeneity of variance is valid, ANOVA test statistics can be applied. Within Table 5 , degrees of freedom (df) for these tests are (df1) 4 and (df2) 295 respectively. 
Table 5. Levene and ANOVA test statistics

\begin{tabular}{|c|c|c|c|c|c|c|c|}
\hline \multirow{2}{*}{$\begin{array}{c}\text { Levene } \\
\text { Statistic } \\
4.722\end{array}$} & \multirow{2}{*}{$\begin{array}{c}\mathbf{P} \\
0.001\end{array}$} & \multirow{2}{*}{$\begin{array}{c}\begin{array}{c}\text { Decision of } \\
\text { Hypothesis* }\end{array} \\
\text { Invalid }\end{array}$} & \multicolumn{2}{|c|}{$\begin{array}{c}\text { Assumption of } \\
\text { Homogeneity of } \\
\text { Variance* }\end{array}$} & \multirow{2}{*}{$\begin{array}{c}\text { Hypothesis } \\
\text { F } \\
2.043\end{array}$} & \multirow{2}{*}{$\begin{array}{c}\text { ANOVA } \\
\mathbf{P} \\
0.088\end{array}$} & \multirow{3}{*}{$\begin{array}{r}\begin{array}{c}\text { Decision of } \\
\text { Hypothesis* }\end{array} \\
\text { Rejected }\end{array}$} \\
\hline & & & & & & & \\
\hline & & & & H011 & & & \\
\hline 1.476 & 0.209 & Valid & & H012 & 4.694 & 0.001 & Rejected \\
\hline 3.254 & 0.012 & Invalid & Age & H013 & 1.007 & 0.404 & Accepted \\
\hline 1.427 & 0.225 & Valid & & H014 & 0.565 & 0.688 & Accepted \\
\hline 4.225 & 0.002 & Invalid & & H015 & 1.761 & 0.137 & Accepted \\
\hline 1.509 & 0.200 & Valid & & H021 & 1.546 & 0.189 & Accepted \\
\hline 2.733 & 0.029 & Invalid & $\begin{array}{l}\text { Empl } \\
\text { ovme }\end{array}$ & H022 & 4.175 & 0.003 & Rejected \\
\hline 2.669 & 0.033 & Invalid & nt & H023 & 1.537 & 0.191 & Accepted \\
\hline 0.087 & 0.987 & Valid & $\begin{array}{c}\text { Perio } \\
\text { d }\end{array}$ & H024 & 0.968 & 0.425 & Accepted \\
\hline 1.629 & 0.167 & Valid & & H025 & 0.157 & 0.960 & Accepted \\
\hline 2.069 & 0.085 & Valid & & H031 & 1.348 & 0.252 & Accepted \\
\hline 1.222 & 0.301 & Valid & & H032 & 0.899 & 0.465 & Accepted \\
\hline 0.874 & 0.480 & Valid & ation & H033 & 0.586 & 0.673 & Accepted \\
\hline 0.960 & 0.430 & Valid & Level & H034 & 0.475 & 0.754 & Accepted \\
\hline 1.750 & 0.139 & Valid & & H035 & 2.636 & 0.034 & Rejected \\
\hline
\end{tabular}

$* 5 \%$ validity of significance level

Validity of homogeneity assumption is shown by accepting the null hypothesis as " $\mathrm{H}_{0}$ : Group variances are homogeneous (equal)" for those with Levene test statistic p value greater than 0.05 in Table 5. Besides, the hypothesis with invalid assumption is not taken into account in Levene statistics. Subsequently, in Table 5, only $\mathrm{H}_{012}$ hypothesis of age and $\mathrm{H}_{035}$ hypothesis of education level are evaluated in ANOVA test. Therefore, the $\mathrm{H}_{012}$ age-related hypothesis "There is no statistically significant difference in their opinion for $\mathrm{F} 2$ between age groups" and $\mathrm{H}_{035}$ education levelrelated hypothesis "There is no statistically significant difference in their opinion for F5 between education levels" are used. It means that alternative hypothesis $\left(\mathrm{H}_{\mathrm{A} 12}\right)$ and $\left(\mathrm{H}_{\mathrm{A} 35}\right)$ are accepted as there are statistical differences in these different groups. Consequently, Post Hoc tests as an integral part of ANOVA are applied to explore differences between multiple groups' means in order to understand which groups these differences originating from. In this study, "Tukey test" as the most common Post Hoc test is employed. Finally, result of Post Hoc test analysis for the alternative hypothesis of $\mathrm{H}_{\mathrm{A} 12}$ "There is a significant difference in in their opinion for $\mathrm{F} 2$ between age groups". Post Hoc test shows that the alternative hypothesis of $\mathrm{H}_{\mathrm{A} 12}$ "There is a significant difference in their opinion for F2 between age groups" has statistically differences between 18-21 Age and 22-25 Age;18-21 Age and 30-33 Age; 18-21 Age and $34 \&$ Over Age. This means that the 18-21 age group (excluding the 26-29 age 
group) suggests that the F2 factor (i.e. employee perception of in-service training) is less important than the other age groups (i.e. 22-25, 30-33, and 34 \& Over).

Result of Post Hoc test analysis for these alternative hypothesis of $\mathrm{H}_{\mathrm{A} 35}$ "There is a significant difference in their opinion for F5 between various education levels". Post Hoc test shows that the alternative hypothesis of $\mathrm{H}_{\mathrm{A} 35}$ "There is a significant difference in their opinion for F5 between various education levels" has statistically differences between High School and Undergraduate degree. This means that the High School group suggests that the F5 factor (i.e. Employees Perception of Skills \& Performance Development Oppurtunities) is less important for them than Undergraduate degree level.

When age, gender, marital status, employment period and education levels are considered in the study, statistically significant differences are:

- "There is a significant difference in their opinion for F2 between age groups"

- "There is a significant difference in their opinion for F5 between various education levels".

\section{Step 4:}

A second order confirmatory factor analysis is performed to determine whether the Call Center Employee Satisfaction of the five factors from the EFA can be accepted as sub-dimensions of the Satisfaction of Call Center Employees (SCCE). Second level confirmatory factor analysis is a sub-topic of Structural Equation Model (SEM) to investigate the causal relationship between observed and latent variables (Dimitrov, 2006:432).

Related Alternative hypothesis for SCCE are tested through SEM as follows:

- $\mathrm{H}_{\mathrm{A} 1}$ : when Employees Perception of Employers' Management Style (F1) has increased, SCCE is improved.

- $\mathrm{H}_{\mathrm{A} 2}$ : when Employees Perception of In-Service Training (F2) has increased, SCCE is improved.

- $\mathrm{H}_{\mathrm{A} 3}$ : when Employees Perception of Collaboration and Teamwork (F3) has increased, SCCE is improved.

- $\mathrm{H}_{\mathrm{A} 4}$ : when Employees Perception of Working Conditions (F4) has increased, SCCE is improved.

- $\mathrm{H}_{\mathrm{A} 5}$ : when Employees Perception of Skills \& Performance Development Opportunities (F5) has increased, SCCE is improved.

Table 6 shows t-test values of alternative hypothesis used in SEM results.

Table 6. t-test of alternative hypothesis used in SEM results

\begin{tabular}{|c|c|c|c|}
\hline Hypothesis & Standard Loads & t Value & $\mathbf{R}^{\mathbf{2}}$ \\
\hline $\mathrm{H}_{\mathrm{A} 1}$ & 0.749 & $10.732 *$ & 0.56 \\
\hline $\mathrm{H}_{\mathrm{A} 2}$ & 0.661 & $10.202 *$ & 0.44 \\
\hline $\mathrm{H}_{\mathrm{A} 3}$ & 0.82 & $11.578^{*}$ & 0.67 \\
\hline $\mathrm{H}_{\mathrm{A} 4}$ & 0.627 & $9.761 *$ & 0.39 \\
\hline $\mathrm{H}_{\mathrm{A} 5}$ & 0.807 & $12.310 *$ & 0.65 \\
\hline
\end{tabular}

$5 \%$ validity of significance level 
In addition, $\mathrm{R}^{2}$ values indicate that each question item has a positive effect on its factor and therefore it will positively affect the call center employee satisfaction. Meanwhile, $\mathrm{CR}$ ( $\mathrm{t}$ value) values of these question items show that all question items are statistically significant.

SEM results are shown in Figure 1 and Table 9.

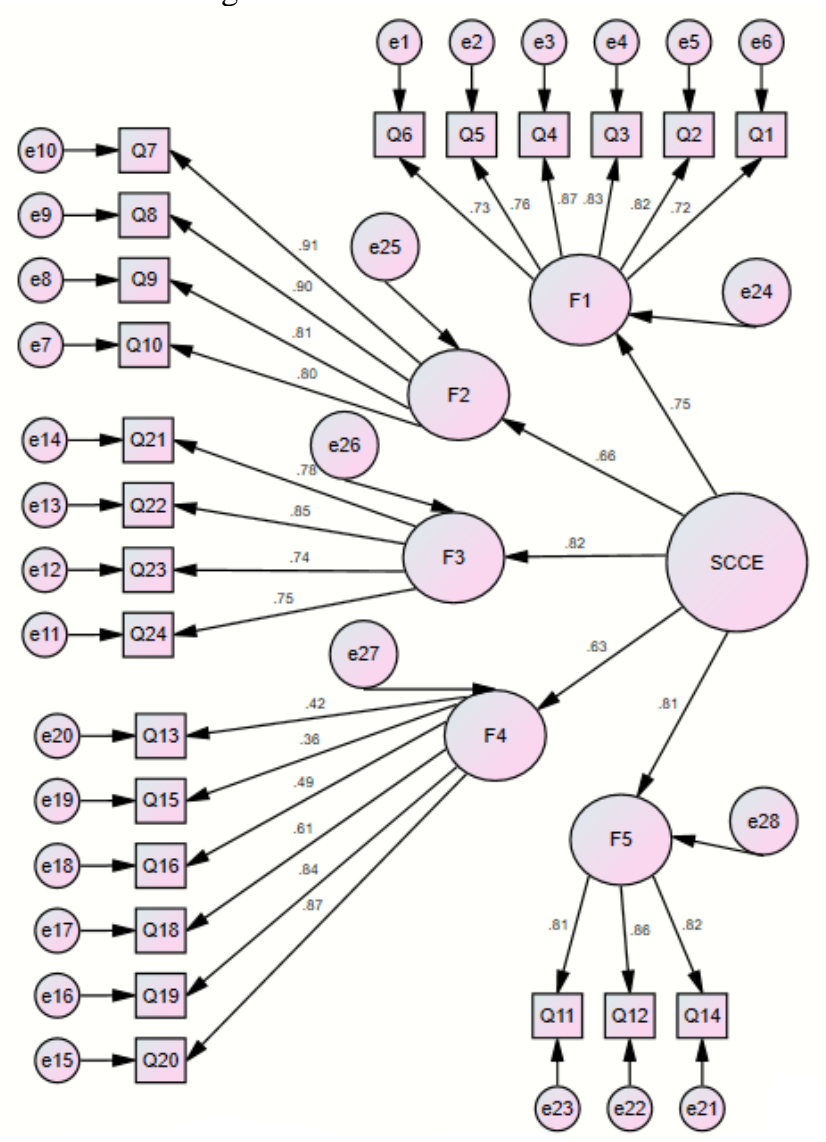

Figure 1. Second Order Confirmatory Factor Analysis Model

When factors loads are ranked in Figure 1, the most important factor positively affecting call center employee satisfaction is F3 (0.82), the second factor is F5 (0.81), the third factor is F1 (0.75), the fourth factor is F2 (0.66) and F4 (0.63) with the least affecting factor in the study. 
Table 7. Second Order Confirmatory Factor Analysis Fit Index Result

\begin{tabular}{|c|c|c|c|c|c|}
\hline \multirow{2}{*}{ Main Dimension } & \multicolumn{5}{|c|}{ Fitness Index } \\
\cline { 2 - 6 } & $\chi^{2}$ & df & $\chi^{2} / \mathrm{df}$ & CFI & RMSEA \\
\hline & & & & & \\
SCCE & 516.854 & 225 & 2.297 & 0.930 & 0.066 \\
\hline
\end{tabular}

In Table 7, the ratio $\chi^{2} / \mathrm{df}$ (2.297) between 2 and 3 is"good" or "acceptable" under the Fit Index model (Schermelleh-Engel, Moosbrugger and Müller, 2003:33), the CFI value (0.930) being equal to or greater than 0.90 is "acceptable" (Westland, 2015:56) and the RMSEA value (0.066) is adequate fit because RMSEA is less than or equal to 0.08. (Westland, 2015:57). As a result of these findings, Second Order Confirmatory Factor Analysis shows that these five factors are sub-dimensions of call center employee satisfaction, and the model becomes valid.

Call centre managers should consider these five factors being statistically significant sub-dimensions of employees' satisfaction in call centers in Turkey. Importantly, when each factor needs to be analysed in details, the relevant question items in each factors can be employed for increasing employee satisfaction.

\section{Conclusions and Practical Implications}

Structural equation model as the general framework is used to test for modelling scenarios generator affecting the call center employee satisfaction by exploring the influence of the demographic factors on employees' satisfaction in call centres in this study. Consequently, the factors affecting their satisfaction are respectively:

- F3: Employees perception of collaboration and teamwork,

- F5: Employees perception of Skills \& Performance development opportunities,

- F1: Employees perception of employers' management style,

- F2: Employees perception of in-service training,

- F4: Employees perception of working conditions.

Firstly, regarding the most influential factor as employees' perception of collaboration and teamwork (F3), our study demonstrates that employee satisfaction in call centres can be achieved as a direct result of communication, collaboration and trust in employees' relationships in their jobs. While both collaboration and teamwork comprise a group of employees working together towards completing their shared goal in call centres, these social activities require a change in organisational culture coinciding with employees' satisfaction. In fact, satisfaction is a result of investment in collaborative and teamwork activities which, in turn, is perceived to contribute to project performance and management. Specifically, this can be achived through creation of support and collaboration habits at work (Q22), collective use of shared knowledge (Q24), managers dealing with the employees' personal problems (Q23), and communication between employers and employees $(\mathrm{Q} 21)$. 
Secondly, regarding the second most influential factor as employees' perception of skills \& performance development opportunities (F5), this study demonstrates that employee satisfaction in call centres can be achieved as a direct result of their creative problem-solving skills, solid knowledge base in tasks, and taking ownership at their tasks. While such skills and performance developments in call centres can encourage employees to take ownership of the development of their own practice, evaluate own performance and take leadership capacity in their own learning process, such individual activities require an organisational culture accommodating innovation and performancing monitoring strategies coinciding with employees' satisfaction in the study. Specifically, this can be achived through demonstrating their abilities and skills at work (Q11), their application of innovation at work (Q14), and learning new things to improve themselves at work (Q12).

Next, employees' perception of employers' management style (F1) relates directly to leadership styles for employee satisfaction in call centres in terms of strategic effective business planning processes, perceived fairness, supervisory support, trust, security, motivation, empowerment, engagement, teamworks and communication. Specifically, this can be achived through their employer creating opportunities and finding alternative solutions (Q4), their employer considering and listening the employee issues (Q2), their employer taking care of the employee and values the employee contributions (Q3), the employee appreciating the work being done and appreciating the employee achievements (Q5), their employee planning and managing the workload (Q1) and their employer being fair and the workload having a balanced distribution (Q6).

Last, employees' perception of in-service training (F2) has the least influential factor affecting employee satisfaction by relating directly to companies' investment on the employees' knowledge developments. When these developmental opportunities are considered as training sessions being delivered, the subjects (relevance) of these training sessions (Q8), its content (Q7), timing (Q9), and the trainers become predictive factors of employees' satisfaction in call centres. Finally, the study shows that employees perception of working conditions (F4) are related to IT systems, facilities and physical working environment including my performance recorded on the computer systems (Q19), employees' lunch break provided (Q13), our computer program is suitable and sufficient (Q20), layout of our office space (Q16), facilities for lunch, coffee and soft-drinks etc. (15), and monitoring and implementation of new technologies at work (18).

Finally, this study concludes in the call centre that there are statistically significant differences between genders in call centres for both Employees' Perception of Employers' Management Style (F1 factor) and Employees' Perception of Skills \& Performance Development Opportunities (F5 factor) in Turkey. In addition, the 1821 age group (excluding 26-29 age group) suggests that the employee perception of in-service training (F2 factor) is less important for them than the other age groups (i.e. 22-25, 30-33, and 34 \& Over). Meanwhile, the High School group suggests that the Employees Perception of Skills \& Performance Development Oppurtunities (F5 factor) is less important for them than undergraduate degree level. Call centre managers should consider these five factors being statistically significant subdimensions of employees' satisfaction in call centers in Turkey. Importantly, when each factor needs to be analysed in details, the relevant question items in each factors can be employed for increasing employee satisfaction. 


\section{References}

Anagnoste, S. (2018, May). Robotic Automation Process-The operating system for the digital enterprise. In Proceedings of the International Conference on Business Excellence, 12(1), 54-69. Sciendo.

Berman, L., Jackson, J., Miller, K., Kowalski, R., Kolm, P. and Luks, F. I. (2018). Expert surgical consensus for prenatal counseling using the Delphi method. Journal of Pediatric Surgery, 53(8), 1592-1599.

Call Center Association. (2017). 2017 Call center association market research report, 1-71. Retrived from: https://www.cagrimerkezleridernegi.org/Public/Upload/ Catalog /KPI8I7JCAEW631A.pdf

Call Center Association. (2019). 2019 Call center association market research report, 1-16. Retrived from: https://www.cagrimerkezleridernegi.org/Public/Upload/ Catalog /V3EXWU4L447QLVW.pdf

Callaghan, F. (2017). An investigation into the motivational factors of call centre workers and the impact positive and negative forms of feedback have on employee performance, Master dissertation, 1-103. Retrived from https://research.thea.ie/ handle/20.500.12065/2555

Chicu, D., del Mar Pàmies, M., Ryan, G. and Cross, C. (2019). Exploring the influence of the human factor on customer satisfaction in call centres. BRQ Business Research Quarterly, 22(2), 83-95.

Choi, S., Cheong, K. K. and Feinberg, R. A. (2012). Moderating effects of supervisor support, monetary rewards, and career paths on the relationship between job burnout and turnover intentions in the context of call centers. Managing Service Quality: An International Journal, 492-516.

Cottam, T. (2020). CONTACT CENTRE 2025: Trends, opportunities and strategies. NICE. Retrived from https://www.nice.com/optimizing-customer-engagements/Lists/ WhitePapers/Contact_centre_2025.pdf

Çelik, N. (2016). Development of a decision support system for the solving problems of Turkey call center sector. Journal of International Social Research, 9(42), 14451453.

Dimitrov, D. M. (2006). Comparing groups on latent variables: A structural equation modeling approach. Work, 26(4), 429-436.

Doğrular, T. (2020). Korono etkisi ile çağri merkezlerinin değişen rolü. Call Centers Association. Retrived from https://www.cagrimerkezleridernegi.org/haberdetay/7185

Gürbüz, S. and Şahin, F. (2016). Sosyal bilimlerde araştırma yöntemleri (3. Bask1). Ankara: Seçkin Yayıncılık.

Kisiel, A. (2013). Performance measurement and job satisfaction in call centre. Master Dissertation, Dublin Business School, 1-88. Retrived from http://hdl.handle.net/10788/1675

Marr, B. and Parry, S. (2004). Sense and respond performance management at Fujitsu: Lessons, pitfalls, and achievements. In PMA 2004 Conference Proceedings, 55-62. 
Poddar, A. and Madupalli, R. (2012). Problematic customers and turnover intentions of customer service employees. Journal of Services Marketing.

Richardson, R. and Gillespie, A. (2003). The call of the wild: Call centers and economic development in rural areas. Growth and Change, 34(1), 87-108.

Rose, E. and Wright, G. (2005). Satisfaction and dimensions of control among call centre customer service representatives. The International Journal of Human Resource Management, 16(1), 136-160.

Schermelleh-Engel, K., Moosbrugger, H. and Müller, H. (2003). Evaluating the fit of structural equation models: Tests of significance and descriptive goodness-of-fit measures. Methods of Psychological Research Online, 8(2), 23-74.

SERKA. (2011). "TRA2 bölgesinin kalkinmasinda çağri merkezi firsati”, Kars: Serhat Kalkınma Ajansı Yayını, 1-64. Retrived from http://www.serka.gov.tr/store/file/common/e8dbe4eae6eb57962b6a38559aa785c0.p df

Singh, P. and Pandey, A. (2005). Women in call centres. Economic and Political Weekly, 684-688.

Syam, N. and Sharma, A. (2018). Waiting for a sales renaissance in the fourth industrial revolution: Machine learning and artificial intelligence in sales research and practice. Industrial Marketing Management, 69, 135-146.

Yang, H. C., Ju, Y. H. and Lee, Y. C. (2016). Effects of job stress on self-esteem, job satisfaction, and turnover intention. Journal of Transnational Management, 21(1), 2939.

Westland, J. C. (2015). Data collection, control, and sample size. In Structural equation models, 1-175. Springer, Cham. 